\title{
Problem Analysis of Elementary School Children as Planning Assesment Program Guidance and Counseling
}

\section{Muhamad Chamdani}

Universitas Sebelas Maret

muhamad_chamdani@staff.uns.ac.id

\section{Article History}

accepted 24/09/2019

\begin{abstract}
The research is based on an analysis of the problems of elementary school children and efforts to develop planning and counseling programs. This type of quantitative research with survey sampling techniques. The research location was in the elementary school in Klirong sub-district, Kebumen. Data collection techniques using observation, interviews, and documentation methods. The results showed that there were several types of problems of elementary school children so that there was a need for planning counseling and programs to help elementary students optimal development.
\end{abstract}

Keywords: problem childrens, planning program's, guidance and counseling

\begin{abstract}
Abstrak
Penelitian didasarkan pada analisis permasalahan anak sekolah dasar dan upaya pengembangan perencanaan program bimbingan dan konseling. Jenis penelitian kuantitatif dengan teknik pengambilan sampel survey. Lokasi penelitian di sekolah dasar sekecamatan Klirong, Kebumen. Teknik pengumpulan data menggunakan observasi, wawancara, dan metode dokumentasi. Hasil penelitian menunjukkan adanya beberapa jenis masalah anak sekolah dasar sehingga perlu adanya perencanaan program bimbingan dan konseling untuk membantu siswa sekolah dasar berkembang optimal.
\end{abstract}

Kata kunci: masalah anak, perencanaan program, bimbingan dan konseling

Social, Humanities, and Education Studies (SHEs): Conference Series https://jurnal.uns.ac.id/shes

p-ISSN 2620-9284 e-ISSN 2620-9292 


\section{PENDAHULUAN}

Tujuan pendidikan di Indonesia sebagaimana tercantum dalam Undang-Undang nomr 20 tahun 2003 tentang Sitem Pendidikan Nasional pasal 3 yaitu "Pendidikan Nasional berfungsi mengembangkan kemampuan dan membentuk watak serta peradaban bangsa yang bermartabat dalam rangka mencerdaskan kehidupan bangsa bertujuan untuk berkembangnya potensi peserta didik agar menjadi manusia yang beriman dan bertakwa kepada Tuhan Yang Maha Esa, berakhlak mulia, sehat, berilmu, cakap, kreatif, mandiri dan menjadi warga negara yang demokratis serta bertanggung jawab". Melalui pendidikan, peserta didik dituntun untuk mengembangkan potensi yang dimilikinya agar menjadi pribadi yang matang secara intelektual, jasmani, sosial, dan emosional. Amanah Undang-Undang nomor 20 tahun 2003 tersebut mengisyaratkan bahwa dengan pendidikan dapat membentuk insan Indonesia yang cerdas, berkepribadian serta berkarakter sehingga nantinya akan lahir generasi bangsa yang tumbuh berkembang dengan karakter yang bernafas nilai-nilai luhur bangsa serta agama.

Bimbingan dan Konseling sebagai salah satu bagian integral dari sistem pendidikan memiliki peran penting dalam pengembangan karakter khususnya nilai karakter religius di sekolah. Pentingnya peran guru BK ditegaskan dalam ASCA (American School Counselor Association), 2011 bahwa :

"Professional counselor need to take an active role in initiating, facilitating, and promoting character, education programs in the school curriculum. The professional school counselor as a part of the school community and as a highly resourceful person, takes an active role by working cooperatively with teachers and administration in providing character education in the school as an integral part of the school curriculum and activities"

Konselor sekolah sebagai salah satu stakeholder di sekolah memiliki peran penting untuk mengembangkan karakter peserta didik. Pengembangan karakter khususnya nilai karakter dapat dilakukan melalui kegiatan layanan bimbingan dan konseling dari perencanaan hingga ke tahap evaluasi. Dengan demikian diharapkan peserta didik dapat mengimplementasikan nilai karakter dalam kehidupannya seharihari.

Berdasar uraian diatas kenyataan tidak semua siswa sukses dalam mengikuti studinya. Hal ini karena siswa di sekolah atau madrasah sebagai manusia dapat dipastikan memiliki masalah, tetapi kompleksitas masalah yang dihadapi oleh satu individu dengan individu lainnya berbeda-beda. Tohirin (2010) membedakan masalah : pertama, perkembangan individu. Kedua, perbedaan individu dalam hal : kecerdasan, kecakapan, hasil belajar, bakat, sikap, kebiasaan, pengetahuan, kepribadian, cita-cita, kebutuhan, minat, pola-pola dan tempo perkembangan, ciri-ciri jasmaniah, dan latar belakang lingkungan. Ketiga, kebutuhan individu dalam hal : memperoleh kasih saying, memperoleh harga diri, memperoleh penghargaan yang sama, ingin dikenal, memperoleh prestasi dan posisi, untuk dibutuhkan orang lain, merasa bagian dari kelompok, rasa aman dan perlindungan diri, dan untuk memperoleh kemerdekaan diri. Keempat, penyesuaian diri dan kelainan tingkah laku. Kelima, masalah belajar. M. Hamdan Adz-Dzaky dalam Tohirin (2010) mengklasifikasikan masalah individu termasuk siswa antara lain, pertama, masalah atau kasus yang berhubungan problematika individu dengan Tuhannya. Kedua, masalah individu dengan dirinya sendiri. Ketiga, individu dengan lingkungan keluarganya. Keempat, individu dengan lingkungan kerja dan kelima, individu dengan lingkungan sosialnya.

Setiap anak dipastikan memiliki masalah tergantung berat dan ringannya suatu masalah yang dihadapi. Masalah, bisa diatasi setiap diri individu namun demikian ada juga yang tidak bisa mengatasinya. Masalah yang muncul dan dirasakan siswa akan mengakibatkan terganggunya kegiatan belajar siswa. Seperti yang dikemukakan oleh Syamsu Yusuf dan Juntika Nurihsan (2009) yang menyatakan bahwa "perasaan yang 
akan timbul dari tidak terselesaikannya suatu masalah yang dialami oleh individu yaitu perasaan rendah diri, perasaan tidak mampu, perasaan gagal, dan perasaan bersalah". Masalah-masalah yang dialami oleh individu itu dapat juga dilihat dari ciri-ciri yang ditampilkannya. Prayitno (2004) mengemukakan beberapa ciri-ciri masalah yaitu : (a) sesuatu yang tidak disukai adanya, (b) sesuatu yang dapat menghambat, menimbulkan atau mendatangkan kesulitan baik untuk sekarang maupun yang akan datang. Masalah dapat disebabkan oleh faktor dalam maupun luar diri individu yang menimbulkan rasa ketidaksenangan yang dapat berpengaruh kepada aktivitas individu.

Permendikbud RI No.111 Tahun 2014 Tentang Bimbingan dan Konseling Pada Pendidikan Dasar dan Pendidikan Menengah menjelaskan bahwa layanan Bimbingan dan Konseling diselenggarakan di dalam kelas dan di luar kelas. Kegiatan bimbingan dan konseling di dalam kelas dan di luar kelas merupakan satu kesatuan dalam layanan profesional bidang bimbingan dan konseling. Layanan dirancang dan dilaksanakan dengan memperhatikan keseimbangan dan kesinambungan program antarkelas dan antar jenjang kelas, serta mensinkronkan dengan kegiatan pembelajaran mata pelajaran dan kegiatan ekstra kurikuler.

Berdasarkan latar belakang dan kenyataan adanya masalah tersebut maka guru bimbingan atau petugas bimbingan dapat menganalisis masalah-masalah yang terjadi pada anak sekolah di kelas untuk dijadikan penilaian dalam merencanakan program bimbingan dan konseling.

\section{METODE}

Penelitian ini adalah penelitian deskriptif . Populasi penelitian 3931 siswa sekolah dasar di Kecamatan Klirong Kabupaten Kebumen. Pengambilan data dengan cara observasi dan wawancara kepada guru kelas I sampai kelas VI. Data yang diperoleh dianalisis dengan menggunakan teknik persentase.

\section{HASIL DAN PEMBAHASAN}

Bimbingan, sebagai upaya pendidikan, diartikan sebagai proses bantuan kepada individu untuk mencapai tingkat perkembangan diri secara optimum di dalam navigasi hidupnya secara mandiri. Bantuan dalam arti bimbingan yaitu memfasilitasi individu untuk mengembangkan kemampuan memilih dan mengambil keputusan atas tanggung jawab sendiri. Kondisi perkembangan optimum adalah kondisi dinamis yang ditandai dengan kesiapan dan kemampuan individu untuk memperbaiki diri (self-improvement) agar dia menjadi pribadi yang berfungsi penuh (fully-fungctioning) di dalam lingkungannya, Kartadinata (2011). Sedangkan, tujuan utama layanan bimbingan dan konseling di sekolah adalah memberikan dukungan pada pencapaian kematangan kepribadian, keterampilan sosial, kemampuan akademik, dan bermuara pada terbentuknya kematangan karir individual yang diharapkan dapat bermanfaat di masa yang akan datang, Fatur Rahman (2009).

Tabel Analisis Kelas, Jumlah Siswa, dan Jenis Masalah di Kecamatan Klirong

\begin{tabular}{cccccccc}
\hline \multirow{2}{*}{ Kelas } & $\begin{array}{c}\text { Jumlah } \\
\text { Siswa }\end{array}$ & $\begin{array}{c}\text { Jumlah } \\
\text { Masalah }\end{array}$ & $\begin{array}{c}\text { Masalah } \\
\text { Belajar }\end{array}$ & $\begin{array}{c}\text { Masalah } \\
\text { Sosial }\end{array}$ & $\begin{array}{c}\text { Masalah } \\
\text { Perkembangan }\end{array}$ & $\begin{array}{c}\text { Masalah } \\
\text { Disiplin }\end{array}$ & $\begin{array}{c}\text { Masalah } \\
\text { Lainnya }\end{array}$ \\
\hline I & 502 & 102 & 59 & 26 & 4 & 15 & 8 \\
II & 612 & 131 & 78 & 19 & 12 & 10 & 12 \\
III & 661 & 125 & 56 & 25 & 15 & 15 & 14 \\
IV & 679 & 140 & 76 & 21 & 20 & 12 & 11 \\
V & 698 & 149 & 85 & 29 & 14 & 20 & 9 \\
VI & 779 & 150 & 89 & 20 & 20 & 13 & 8 \\
Jumlah & $\mathbf{3 9 3 1}$ & $\mathbf{7 9 7}$ & $\mathbf{4 4 3}$ & $\mathbf{1 4 0}$ & $\mathbf{8 5}$ & $\mathbf{8 5}$ & $\mathbf{6 2}$ \\
\multicolumn{2}{c}{$\%$} & $\mathbf{2 0 , 2 7 4 \%}$ & $\mathbf{1 1 , 2 6 9 \%}$ & $\mathbf{3 , 5 6 1 \%}$ & $\mathbf{2 , 1 6 2 \%}$ & $\mathbf{2 , 1 6 2 \%}$ & $\mathbf{1 , 5 7 7 \%}$ \\
\hline
\end{tabular}


Berdasarkan tabel diatas dapat dideskripsikan bahwa di Kecamatan Klirong Kabupaten Kebumen menurut data survei jumlah siswa dari kelas I sampai dengan kelas IV adalah 3931. Jumlah masalah yang dihadapi siswa sebesar 797 atau $20,274 \%$ yang terdiri dari masalah belajar $11,27 \%$, masalah sosial 3,56\%, masalah perkembangan anak 2,16\%, masalah kedisiplinan dan ketertiban 2,16\%, dan masalah lain $1,58 \%$. Artinya, secara umum masalah belajar menduduki persentase tertinggi yang berarti dalam membuat perencanaan program Bimbingan dan Konseling perlu mendapat prioritas yang utama. Kemudian dilanjutkan dengan program-program yang lain sesuai dengan kebutuhan siswa dan program sekolah.

Depdiknas (2008) menjelaskan bahwa pada saat ini telah terjadi perubahan paradigma pendekatan bimbingan dan konseling, yaitu dari pendekatan yang berorientasi tradisional, remedial, klinis, dan terpusat pada konselor, kepada pendekatan yang berorientasi perkembangan dan preventif. Pendekatan bimbingan dan konseling perkembangan (Developmental Guidance and Counseling) atau bimbingan dan konseling komprehensif (Comprehensive Guidance and Counseling) didasarkan pada upaya pencapaian tugas perkembangan, pengembangan potensi, dan pengentasan masalah-masalah konseling. Pendekatan bimbingan dan konseling perkembangan ini kemudian dikenal dengan bimbingan dan konseling komprehensif.

Menurut Supriatna (2011), bimbingan dan konseling komprehensif merupakan model bimbingan dan konseling yang berpegang pada prinsip bimbingan dan konseling perkembangan. Bimbingan dan konseling perkembangan bertolak dari asumsi bahwa perkembangan yang sehat terjadi melalui interaksi yang sehat antara individu dengan lingkungannya. Ini berarti bahwa pengembangan lingkungan perkembangan atau ekologi perkembangan manusia merupakan wahana strategis perkembangan siswa yang harus dikembangkan konselor. Lingkungan perkembangan adalah lingkungan belajar yang terstruktur dan secara sengaja dirancang untuk memberi peluang kepada siswa mempelajari perilaku baru, membentuk ekspektasi dan persepsi, memperbaiki dan bahkan mengganti perilaku yang tidak sesuai, memperhalus dan menginternalisasi perilaku. Dalam Permendikbud Nomor 111 Tahun 2014 tentang Pelaksanaan Bimbingan dan Konseling Pada Pendidikan Dasar dan Menengah, dijelaskan bahwa bimbingan dan konseling komprehensif terdiri dari 4 (empat) komponen layanan, yaitu layanan dasar, layanan peminatan dan perencaaan individual, layanan responsif dan dukungan sistem.

Layanan Dasar, sebagai pemberian bantuan melalui kegiatan penyiapan pengalaman terstruktur secara klasikal atau kelompok yang dirancang dan dilaksanakan secara sistematis dalam rangka mengembangkan kemampuan penyesuaian diri yang efektif sesuai dengan tahap dan tugas perkembangan. Strategi layanan dasar yaitu 1) bimbingan klasikal, 2) bimbingan kelompok, 3) media bimbingan kelompok, 4) asesmen kebutuhan. Layanan Peminatan dan Perencanaan Individual , layanan perencanaan individual dan peminatan sebagai layanan untuk merencanakan dan mempersiapkan masa depan peserta didik dengan memperhatikan potensi yang ada pada dirinya termasuk memperhatikan kelebihan dan kekurangan yang dimiliki. Strategi penguatan nilai karakter melalui layanan ini dengan menguatkan dimensi pengalaman agama. Dengan demikian, hal tersebut mendorong peserta didik untuk mengaplikasikan ajaran agama yang dianutnya dalam perencanaan masa depan dan peminatannya. Layanan Responsif, layanan responsif merupakan layanan segera yang diberikan kepada peserta didik untuk menyelesaikan permasalahan peserta didik baik secara langsung maupun tidak langsung. Pengembangan nilai karakter dapat diterapkan ke dalam strategi layanan responsif. Misalnya penekanan dimensi keyakinan agama dalam layanan konseling individu bagi peserta didik/konseli, atau dengan berdoa sebelum kegiatan layanan konseling kelompok dimulai sebagai implementasi dari aspek keyakinan, peribadatan dan penghayatan. Dukungan Sistem Internalisasi nilai karakter dalam dukungan sistem misalnya penelitian guru BK tentang 
penerapan nilai siswa di sekolah atau melalui kegiatan parenting dengan tema "Cara Rasulullah Mendidik Anak". Kemudian bentuk dukungan sistem yang lainnya adalah adanya kolaborasi antara guru BK dengan guru agama dan tokoh agama di lingkungan masyarakat untuk meningkatkan kesadaran dan memberikan pemahaman karakter kepada siswa.

Bimbingan dan konseling merupakan bagian integral dan tidak terpisahkan dari proses pendidikan dan memiliki kontribusi terhadap keberhasilan proses pendidikan di sekolah termasuk madrasah. Hal ini berarti proses pendidikan dan pembelajaran di sekolah dan madrasah tidak akan memperoleh hasil yang optimal tanpa didukung oleh penyelenggaraan layanan bimbingan dan konseling di sekolah dan madrasah hanya mungkin dapat dilaksanakan secara baik apabila deprogramkan secara baik pula.

Agar pelayanan bimbingan dan konseling di sekolah dan madrasah dapat terlaksana secara efektif dan efisien serta tujuannya dapat tercapai secara efektif dan efisien pula maka harus disusun programnya secara terencana dan sistematis. Dengan perkataan lain, pelayanan bimbingan dan konseling di sekolah dan madrasah perlu direncanakan, dilaksanakan, dan dinilai secara sistematis sehingga dirasakan manfaatnya oleh berbagai pihak.

\section{SIMPULAN}

Berdasar hasil pengolahan data yang telah dikemukakan pada hasil dan pembahasan, maka kesimpulan penelitian ini adalah (1) permasalahan yang dialami siswa SD kecamatan Klirong adalah : masalah belajar 11,26\%, masalah sosial 3,56\%, masalah perkembangan 2,17\%, masalah ketertiban dan disiplin 2,16\% serta masalah yang lainnya $1,58 \%$. Masalah yang dominan dihadapi siswa SD di Kecamatan Klirong yaitu masalah belajar. (2) berdasarkan masalah-masalah yang dihadapi siswa sekolah dasar, maka dapat dipertimbangkan dalam merencanakan program bimbingan dan konseling di sekolah sehingga perencanaan, pelaksanaan, dan evaluasi tepat sasaran dan dapat berguna membantu mengoptimalkan perkembangan siswa.

\section{DAFTAR PUSTAKA}

ASCA (2010). Comprehensive School Program Guide. New York : Institute of Technology.

Ashari, Waskam \& Sugiharto, DYP \& Supriyo. (2016, Desember 2016). Pengembangan Model Konseling Kelompok Dengan Teknik Pengelolaan Dlri Untuk Meningkatkan Efikasi Diri Siswa Terhadap Perilaku Beresiko Merokok di SMK YPT 1 Purbalingga. Diakses dari Jurnal Bimbingan Konseling UNNES, bulan September 2019.

Kartadinata, S (2011). Menguak Tabir Bimbingan dan Konseling sebagai upaya Pedagogis. Bandung : UPI Press.

Permendikbud RI No. 111 Tahun 2014 tentang Bimbingan dan Konseling pada Pendidikan Dasar dan Menengah.

Prayitno, dan Amti, Erman. (2009). Dasar-Dasar Bimbingan dan Konseling. Jakarta : PT Asdi Mahasatya.

Supriatna, Mamat. (2011). Bimbingan dan Konseling Berbasis Kompetensi. Jakarta : PT. RajaGrafindo Persada.

Tohirin. (2010). Bimbingan dan Konseling di Sekolah dan Madrasah (berbasis integrasi). Jakarta : PT. RajaGrafindo Persada.

Ulfa, Sugiyo, Purwanto edi. (2014, Juni, 2014). Model Pengembangan Instrumen Supervisi Bimbingan dan Konseling. Diakses dari Jurnal Bimbingan Konseling UNNES, bulan September 2019.

Undang-Undang Nomor 20 Tahun 2003 tentang Sistem Pendidikan Nasional.

Yusuf S. \& Nurihsan, J. (2009). Landasan Bimbingan dan Konseling. Bandung : PT. RosdaKarya. 